\title{
Paenibacillus wooponensis sp. nov., isolated from wetland freshwater
}

Correspondence

Chi Nam Seong

scnu@scnu.ac.kr
The genus Paenibacillus was proposed by Ash et al. (1993) to accommodate the members of 'group 3' within the genus Bacillus. At the time of writing, there were 112 species of the genus Paenibacillus with validly published names (http:// www.bacterio.cict.fr/p/paenibacillus.html). Members of the genus Paenibacillus possess the general characteristics of the genus Bacillus, being aerobic or facultatively anaerobic, endospore-forming and rod-shaped. Members of the genus Paenibacillus have physiologically diverse characteristics and some species are known to secrete a variety of extracellular enzymes and produce antibiotic substances (Chung et al., 2000; Seo et al., 1999). Species of the genus Paenibacillus have been isolated from a wide range of sources including soil, water, plant rhizospheres, plant materials, food, fodder, faeces and diseased insect larvae (Alexander \& Priest, 1989; Kanzawa et al., 1995; Montefusco et al., 1993; Nakamura, 1984; Seldin et al., 1984; Shida et al., 1997; Yoon et al., 1998).

The GenBank/EMBL/DDBJ accession numbers for the 16S rRNA and $r p o B$ gene sequences of strain WPCB018 ${ }^{\top}$ are EU939687 and H0596203, respectively.

Three supplementary figures and one supplementary table are available with the online version of this paper.
Recently, two species of the genus Paenibacillus, P. humicus and $P$. pasadenensis, were distinguished from other closely related species by having a high DNA $\mathrm{G}+\mathrm{C}$ content (>58 mol\%), together forming a distinct lineage within the genus Paenibacillus (Vaz-Moreira et al., 2007).

During the course of a study to estimate the bacterial diversity of Woopo wetland (Baik et al., 2008), one bacterial strain, designated WPCB $018^{\mathrm{T}}$, was identified as a member of the genus Paenibacillus. The wetland is located at the eastern part of the Nakdong River and is represented by a large oxbow lake as well as small ponds and marshes. Surface water is persistent, even in the dry season, and extensive flooding occurs in surrounding areas during the rainy season (http://ramsar.wetlands.org). Strain WPCB $018^{\mathrm{T}}$ was isolated in a previous study (Baik et al., 2008) from a surface water sample taken from the Woopo freshwater wetland in July 2000, where the water temperature was $27^{\circ} \mathrm{C}$ and $\mathrm{pH}$ was 7.4. Isolation was achieved by using PYGV (Staley, 1968) and R2A agar (Becton Dickinson), incubated at $25{ }^{\circ} \mathrm{C}$ for 7 days. The isolate was routinely cultured on R2A agar and preserved at $-80{ }^{\circ} \mathrm{C}$ as a suspension in distilled water containing $20 \%$ $(\mathrm{w} / \mathrm{v})$ glycerol. 
DNA preparation, PCR amplification and sequencing of the $16 \mathrm{~S}$ rRNA gene and partial RNA polymerase $\beta$-subunit $(r p o B)$ gene were carried out as described previously (Chun \& Goodfellow, 1995; Dahllöf et al., 2000). Sequence similarities were determined from pairwise $16 \mathrm{~S}$ rRNA gene sequence comparisons using the EzTaxon server (www. eztaxon.org/; Chun et al., 2007). Sequences were aligned by using CLUSTAL_X (Thompson et al., 1997), and the alignment was refined using PHYDIT (Chun, 1995). A total of $1460 \mathrm{nt}$ in unambiguously aligned positions were used for tree reconstruction. Phylogenetic analyses were performed by using the computer packages PHYLIP (Felsenstein, 1993) and PAUP* 4.0 (Swofford, 1998). Phylogenetic trees were inferred using neighbour-joining (Saitou \& Nei, 1987), FitchMargoliash (Fitch \& Margoliash, 1967), maximum-likelihood (Felsenstein, 1993) and maximum-parsimony (Fitch, 1971) algorithms. Distance matrices for the neighbourjoining and Fitch-Margoliash methods were generated according to the model of Jukes \& Cantor (1969). The robustness of the topology in the neighbour-joining phylogenetic tree was evaluated by bootstrap analyses (Felsenstein, 1985) based on 1000 resamplings. Multiple alignments of partial $r p o B$ gene sequences $(374 \mathrm{nt}$ ) were determined using CLUSTAL_X (Thompson et al., 1997) and sequence similarities were calculated using PHYDIT (Chun, 1995). The phylogenetic analysis based on rpoB gene sequences was performed using the methods described above.

Strain WPCB018 ${ }^{\mathrm{T}}$ showed highest $16 \mathrm{~S}$ rRNA gene sequence similarities to Paenibacillus humicus PC- $147^{\mathrm{T}}(97.5 \%)$ and P. pasadenensis SAFN- $007^{\mathrm{T}}$ (96.2 \%) followed by P. pinihumi $\mathrm{S}_{2} 3^{\mathrm{T}}(95.9 \%)$, and displayed $<95.9 \%$ to other members of the genus Paenibacillus. The neighbour-joining tree (Fig. 1a) shows that strain $\mathrm{WPCB} 018^{\mathrm{T}}$ formed a distinct branch within the clade comprising P. humicus $\mathrm{PC}-147^{\mathrm{T}}, P$. pasadenensis $\mathrm{SAFN}-007^{\mathrm{T}}, P$. pinihumi $\mathrm{S} 23^{\mathrm{T}}$ and $P$. tarimensis DSM $10249^{\mathrm{T}}$, as was seen in other trees (Supplementary Fig. $\mathrm{S} 1$, available in IJSEM Online). Partial $r p o B$ gene sequence similarity values of strain WPCB $018^{\mathrm{T}}$ with $P$. pinihumi $\mathrm{S} 23^{\mathrm{T}}$, P. pasadenensis SAFN $-007^{\mathrm{T}}$ and P. humicus $\mathrm{PC}-147^{\mathrm{T}}$ were 86.4, 85.3 and $85.0 \%$, respectively. Although the phylogenetic position of strain WPCB018 ${ }^{\mathrm{T}}$ based on $16 \mathrm{~S}$ rRNA and $r p o B$ gene sequences (Fig. 1b) was slightly different, it was clear that strain WPCB018 ${ }^{\mathrm{T}}$ could be differentiated from its nearest neighbours.

DNA-DNA hybridizations were performed by using the membrane filter technique with the DIG High Prime DNA Labelling and Detection Starter kit II (Roche Molecular Biochemicals) following the method of Lee et al. (2003), except that the hybridization temperature used was $55^{\circ} \mathrm{C}$. DNA-DNA relatedness tests were performed between strain WPCB $018^{\mathrm{T}}$ and the type strains of closely related species of the genus Paenibacillus.

Levels of DNA-DNA relatedness between strain WPCB018 ${ }^{\mathrm{T}}$ and strains $P$. humicus $\mathrm{PC}-147^{\mathrm{T}}, P$. pinihumi $\mathrm{S} 23^{\mathrm{T}}, P$. phyllosphaerae PALXIL04 ${ }^{\mathrm{T}}, P$. pasadenensis SAFN- $007^{\mathrm{T}}$ and P. tarimensis SA-7- $6^{\mathrm{T}}$ were only $10,17,18,19$ and $20 \%$, respectively (Supplementary Table S1). Thus, levels of genetic relatedness according to DNA-DNA hybridization experiments were $>70 \%$, the recommended threshold value for the delineation of bacterial species (Wayne et al., 1987), suggesting that strain WPCB $018^{\mathrm{T}}$ represents a novel species, distinct from its closest relatives.

Growth on various standard bacteriological media was tested by using nutrient agar (NA; Becton Dickinson), tryptic soy agar (TSA; Becton Dickinson) and R2A agar according to the manufacturer's instructions. Cells of strain WPCB $018^{\mathrm{T}}$ were grown on TSA at $30{ }^{\circ} \mathrm{C}$ for 2 days and used for physiological and biochemical tests. Cell morphology was observed by using light microscopy (BX50; Olympus) and scanning electron microscopy (S-4800; Hitachi). Endospore formation was observed by using phase-contrast microscopy (TMS-F; Nikon). Flagellation was determined by using transmission electron microscopy (CM-20; Philips) with cells cultured for $24 \mathrm{~h}$ in tryptic soy broth (TSB; Becton Dickinson). For this purpose, the cells were negatively stained with $1 \%(\mathrm{w} / \mathrm{v})$ phosphotungstic acid and the grids were examined after being air-dried. The Gram-reaction test was performed on cells grown on TSA at $25{ }^{\circ} \mathrm{C}$ for $1-16$ days by using the bioMérieux Gram-stain kit according to the manufacturer's instructions and the Ryu non-staining KOH method (Powers, 1995). Growth at $0-10 \%(\mathrm{w} / \mathrm{v}) \mathrm{NaCl}$ (increments of $1 \%$ ) was investigated in TSB prepared according to the formula of the Becton Dickinson medium except that no $\mathrm{NaCl}$ was used initially. Growth at $\mathrm{pH} 4-10$ was determined using TSB medium containing either $100 \mathrm{mM}$ acetate buffer (for $\mathrm{pH} 4-5$ ), $100 \mathrm{mM}$ phosphate buffer $(\mathrm{pH} 6-8)$ or $100 \mathrm{mM} \mathrm{NaHCO}_{3} /$ $\mathrm{Na}_{2} \mathrm{CO}_{3}$ buffer (pH 9-10) (Breznak \& Costilow, 2007; Yumoto et al., 2004). The optimal temperature and temperature range for growth was tested on TSA at $4-50{ }^{\circ} \mathrm{C}$. Anaerobic growth was tested on TSA for up to 10 days in a jar containing an AnaeroPack-Anaero (Mitsubishi Gas Chemical), which works as oxygen absorber and $\mathrm{CO}_{2}$ generator. Catalase activity was determined from bubble production in a $3 \%(\mathrm{v} / \mathrm{v})$ aqueous hydrogen peroxide solution. Oxidase activity was tested by using a bioMérieux oxidase reagent. Acid production from sugars was tested as described by Yamaguchi \& Yokoe (2000). Nitrate reduction was tested on TSB containing $0.2 \%(\mathrm{w} / \mathrm{v}) \mathrm{KNO}_{3}$ (Skerman, 1967). Hydrogen sulfide production was determined on Kligler iron agar (Becton Dickinson). Hydrolysis of CMcellulose $(1 \%, \mathrm{w} / \mathrm{v})$, casein $(2 \%$ skim milk, w/v), egg yolk $(10 \%, \mathrm{w} / \mathrm{v})$, starch $(0.2 \%, \mathrm{w} / \mathrm{v})$, Tween $20(1 \%$, w/v $)$, Tween $80(1 \%, \mathrm{w} / \mathrm{v})$, L-tyrosine $(0.5 \%, \mathrm{w} / \mathrm{v})$ and xylan $(1 \%$, $\mathrm{w} / \mathrm{v}), \beta$-galactosidase activity, indole production and the Voges-Proskauer reaction were tested as described by Smibert \& Krieg (1994). DNase activity was determined with DNase test agar (Becton Dickinson). Other biochemical and enzymic activity tests were performed using API 20 NE, API 50 CHB and API ZYM kits (bioMérieux) and the GP2 MicroPlate system (Biolog) prepared according to the manufacturer's instructions. Antibiotic resistance was determined using the disc diffusion method with commercial 
(a)

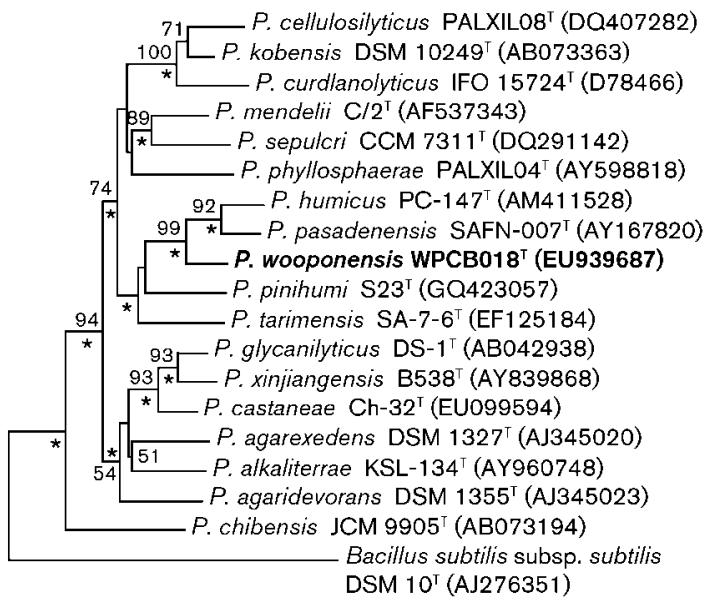

(b) 0.05

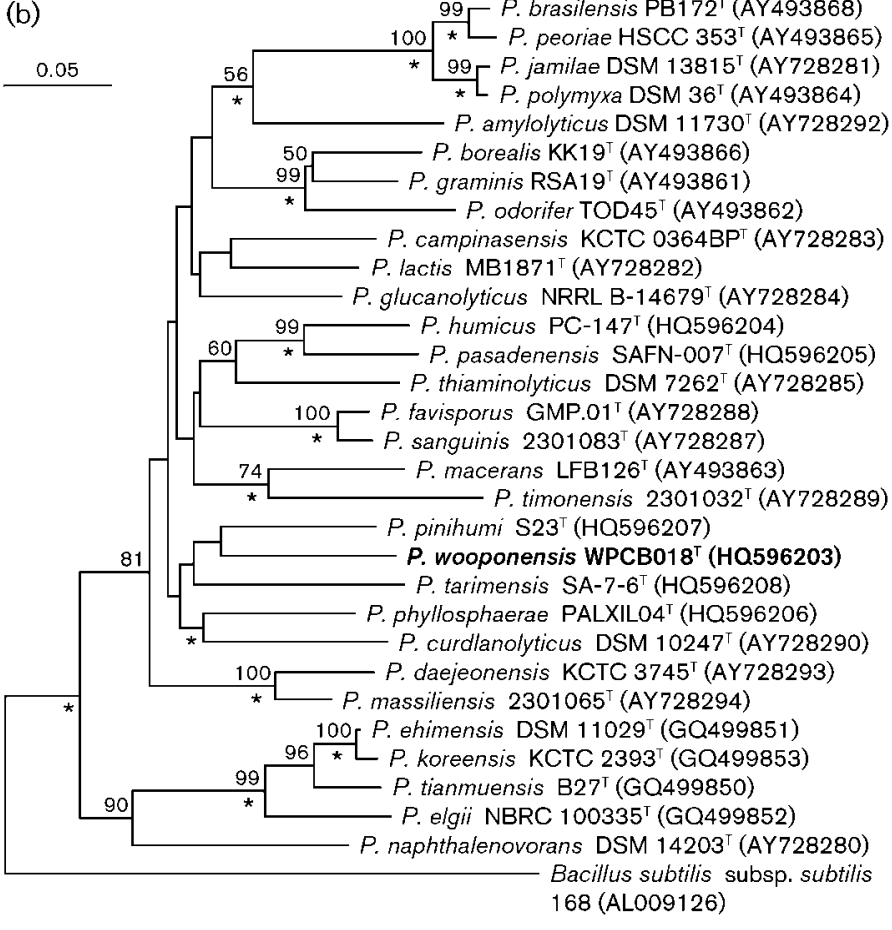

Fig. 1. Neighbour-joining tree based on nearly complete 16S rRNA (a) and partial rpoB (b) gene sequences showing relationships between strain WPCB018 ${ }^{\top}$ and related members of the genus Paenibacillus. Percentage bootstrap values $>50 \%$ (based on 1000 resamplings) are given at branch points. Asterisks indicate that the corresponding nodes (groupings) were also recovered in Fitch-Margoliash, maximumparsimony and maximum-likelihood trees. Bars, 0.01 (a) and 0.05 (b) substitutions per nucleotide position. antibiotic-impregnated discs (BBL Becton Dickinson). After 5 days of incubation at $30{ }^{\circ} \mathrm{C}$ on TSA, the results were interpreted according to the guidelines of the CLSI (2009).

Cells of strain WPCB $018^{\mathrm{T}}$ were Gram-reaction-positive, strictly aerobic, motile and catalase- and oxidase-positive. Vegetative cells were rod-shaped, $0.7-1.0 \times 2.0-5.0 \mu \mathrm{m}$ in size and formed peritrichous flagella on TSB medium (Supplementary Fig. S2). Ellipsoidal spores were formed in swollen sporangia and were in a subterminal position in cells. Colonies of $\mathrm{WPCB} 18^{\mathrm{T}}$ were circular, smooth, opaque, convex, entire and cream-coloured when grown on TSA plates. The diameter of the colonies was $2 \mathrm{~mm}$ after 2 days of growth at $30{ }^{\circ} \mathrm{C}$ on TSA. Strain WPCB $018^{\mathrm{T}}$ grew at $10-37{ }^{\circ} \mathrm{C}$ (optimum $30-35{ }^{\circ} \mathrm{C}$ ) on TSA but not at $40{ }^{\circ} \mathrm{C}$. Strain WPCB $018^{\mathrm{T}}$ grew in TSB media containing
$0-2 \%(w / v) ~ N a C l$ but not at $3 \%(w / v) ~ N a C l$ or above. The $\mathrm{pH}$ range for growth was $\mathrm{pH}$ 5-9 (optimum $\mathrm{pH}$ 6-8). Detailed results of physiological and biochemical analyses are given in Table 1 and in the species description. There were several phenotypic characteristics that readily separated strain $\mathrm{WPCB} 18^{\mathrm{T}}$ from phylogenetically related species; for example, strain WPCB $018^{\mathrm{T}}$ was exclusively positive for DNA hydrolysis and acid phosphatase activity, but negative for starch hydrolysis.

Cellular fatty acids of strain WPCB $018^{\mathrm{T}}$ grown on TSA for 2 days at $30{ }^{\circ} \mathrm{C}$ were prepared (in duplicate) and analysed as methyl esters by GLC according to the instructions of the Microbial Identification System (MIDI). Polar lipids were analysed by using standard procedures (Minnikin et al., 1984). Extracted lipids were separated by two- 
Table 1. Differential characteristics of strain WPCB018 ${ }^{\top}$ and the type strains of related species of the genus Paenibacillus

Strains: 1, WPCB $018^{\mathrm{T}} ; 2$, P. humicus PC- $147^{\mathrm{T}} ; 3$, P. pasadenensis SAFN $-007^{\mathrm{T}} ; 4$, P. pinihumi $\mathrm{S} 23^{\mathrm{T}} ; 5$, P. tarimensis $\mathrm{SA}-7-6^{\mathrm{T}}$. All data are from this study unless otherwise indicated. Data in the parentheses were different from published data. +, Positive; -, negative; $\mathrm{w}$, weakly positive.

\begin{tabular}{|lccccc|}
\hline Characteristic & $\mathbf{1}$ & $\mathbf{2}$ & $\mathbf{3}$ & $\mathbf{4}$ & $\mathbf{5}$ \\
\hline Catalase & + & + & + & - & + \\
Oxidase & + & + & + & + & - \\
Hydrolysis of: & & & & & \\
$\quad$ Casein & + & - & + & $(+)$ & $\mathrm{w}$ \\
DNA & + & - & $\mathrm{w}$ & - & - \\
Starch & - & + & + & + & $(+)$ \\
Tween 20 & + & + & + & - & + \\
Tween 80 & - & + & - & - & - \\
Acid production from: & & & & & \\
D-Fructose & + & - & + & - & - \\
D-Galactose & + & - & + & - & + \\
D-Glucose & + & - & $(+)$ & - & + \\
D-Mannitol & - & $(+)$ & $(+)$ & - & + \\
D-Mannose & + & - & + & - & + \\
Melezitose & + & - & + & - & $\mathrm{W}$ \\
Raffinose & + & - & + & $(+)$ & + \\
Salicin & - & - & + & - & + \\
D-Xylose & + & - & + & $(+)$ & + \\
Enzyme activities (API ZYM): & & & & & \\
Acid phosphatase & + & - & - & - & - \\
Esterase (C4) & + & + & + & - & + \\
$\beta$-Galactosidase & + & + & + & + & - \\
$\alpha$-Glucosidase & - & + & + & - & - \\
$\beta$-Glucosidase & + & + & - & - & + \\
DNA G+C content (mol\%) & 56.0 & $58.0^{a}$ & 63.0 & $49.5^{b}$ & $53.7^{c}$ \\
\hline
\end{tabular}

${ }^{\star}$ Data from: a, Vaz-Moreira et al. (2007); b, Kim et al. (2009); c, Wang et al. (2008).

dimensional TLC and identified by spraying with appropriate detection reagents (Minnikin et al., 1984; Komagata \& Suzuki, 1987). The isomer type of the diamino acid of the cell wall was analysed according to the method of Komagata \& Suzuki (1987). The respiratory quinones were extracted from $300 \mathrm{mg}$ freeze-dried cells, purified according to the method of Minnikin et al. (1984) and analysed by HPLC as described previously (Kroppenstedt, 1985). The DNA G + C content was calculated using the formula described by Mandel et al. (1970). The DNA sample was prepared in duplicate and determined by the thermal denaturation method of Marmur \& Doty (1962).

The major fatty acids of strain $\mathrm{WPCB} 018^{\mathrm{T}}$ comprised branched saturated fatty acid anteiso- $\mathrm{C}_{15: 0}(32.2 \%)$ and straight-chain saturated fatty acids $\mathrm{C}_{16: 0}(20.1 \%)$ and $\mathrm{C}_{18: 0}$ $(18.1 \%)$. The fatty acid profile of strain $\mathrm{WPCB} 018^{\mathrm{T}}$ was similar to those of related species of the genus Paenibacillus, but the respective proportions of predominant fatty acids differed significantly from other species (Table 2); strain WPCB $018^{\mathrm{T}}$ contained larger amounts of $\mathrm{C}_{16: 0}$ and $\mathrm{C}_{18: 0}$, but smaller amounts of anteiso- $\mathrm{C}_{15: 0}$ in strain WPCB018 ${ }^{\mathrm{T}}$.

The polar lipid pattern of strain WPCB $018^{\mathrm{T}}$ was characterized by the presence of diphosphatidylglycerol, phosphatidylethanolamine, unknown aminolipids and unknown aminophospholipids, similar to the profiles of related species of the genus Paenibacillus (Supplementary Fig. S3). The diamino acid in the cell-wall peptidoglycan of strain WPCB $018^{\mathrm{T}}$ was meso-diaminopimelic acid. The predominant isoprenoid quinone was menaquinone with seven isoprene units (MK-7). The DNA G $+\mathrm{C}$ content of strain WPCB $018^{\mathrm{T}}$ was $56.0 \mathrm{~mol} \%$. This high DNA G $+\mathrm{C}$ molar ratio supported its position in a distinct phylogenetic lineage with $P$. humicus and $P$. pasadenensis as shown in Fig. 1(a) (Vaz-Moreira et al., 2007).

On the basis of the phylogenetic, genomic and phenotypic data, strain $\mathrm{WPCB} 18^{\mathrm{T}}$ represents a novel species within the genus Paenibacillus, for which the name Paenibacillus wooponensis sp. nov. is proposed.

Table 2. Cellular fatty acid profiles (\%) of strain WPCB018 and the type strains of related species of the genus Paenibacillus

Strains: 1, WPCB $018^{\mathrm{T}}$; 2, P. humicus PC- $147^{\mathrm{T}} ; 3$, P. pasadenensis SAFN- $007^{\mathrm{T}} ; 4$, P. pinihumi $\mathrm{S} 23^{\mathrm{T}} ; 5$, P. tarimensis SA-7 $-6^{\mathrm{T}}$. Cells of all strains were harvested after cultivation at $30{ }^{\circ} \mathrm{C}$ on TSA medium for 2 days. -, Not detected. All data were obtained in this study.

\begin{tabular}{|c|c|c|c|c|c|}
\hline Fatty acid & 1 & 2 & 3 & 4 & 5 \\
\hline \multicolumn{6}{|c|}{ Straight-chain saturated } \\
\hline $\mathrm{C}_{12: 0}$ & 0.6 & - & - & 0.9 & - \\
\hline $\mathrm{C}_{14: 0}$ & 2.6 & 2.0 & 1.5 & 2.1 & 1.8 \\
\hline $\mathrm{C}_{15: 0}$ & 4.6 & 1.2 & 2.0 & 2.1 & 4.0 \\
\hline $\mathrm{C}_{16: 0}$ & 20.9 & 12.7 & 12.5 & 15.7 & 10.5 \\
\hline $\mathrm{C}_{17: 0}$ & 1.4 & 0.5 & 0.8 & 0.6 & 0.7 \\
\hline $\mathrm{C}_{18: 0}$ & 18.1 & 7.9 & 9.7 & 7.3 & 6.0 \\
\hline \multicolumn{6}{|l|}{ Branched saturated } \\
\hline iso- $\mathrm{C}_{14: 0}$ & 0.8 & 2.3 & 1.4 & 2.1 & 0.8 \\
\hline iso- $\mathrm{C}_{15: 0}$ & 4.6 & 5.3 & 3.3 & 7.9 & 4.8 \\
\hline iso- $\mathrm{C}_{16: 0}$ & 5.2 & 11.3 & 12.9 & 10.5 & 3.8 \\
\hline iso- $\mathrm{C}_{17: 0}$ & 0.8 & 1.4 & 1.4 & 2.1 & 1.4 \\
\hline anteiso- $\mathrm{C}_{15: 0}$ & 32.2 & 46.8 & 43.0 & 42.5 & 50.7 \\
\hline anteiso- $\mathrm{C}_{17: 0}$ & 3.0 & 6.6 & 9.0 & 3.2 & 13.0 \\
\hline \multicolumn{6}{|l|}{ Monounsaturated } \\
\hline $\mathrm{C}_{16: 1} \omega 7 c$ alcohol & - & - & 0.9 & - & - \\
\hline $\mathrm{C}_{16: 1} \omega 11 c$ & - & - & 0.4 & - & 1.0 \\
\hline $\mathrm{C}_{18: 1} \omega 9 c$ & 2.8 & 0.9 & 1.2 & 1.4 & 0.7 \\
\hline $\mathrm{C}_{18: 1} \omega 7 c$ & 3.1 & 1.1 & - & 1.2 & - \\
\hline Summed feature $4^{\star}$ & - & - & - & - & 1.0 \\
\hline
\end{tabular}

* Summed features represent groups of two fatty acids that could not be separated by GLC with the MIDI system. Summed feature 4 contained iso- $\mathrm{C}_{17: 1} \mathrm{I}$ and/or iso- $\mathrm{C}_{17: 1} \mathrm{~B}$. 


\section{Description of Paenibacillus wooponensis sp. nov.}

Paenibacillus wooponensis (woo.po.nen'sis. N.L. masc. adj. wooponensis of or belonging to Woopo wetland, Republic of Korea, the geographical origin of the type strain of the species).

Cells are Gram-reaction-positive, strictly aerobic, motile rods $(0.7-1.0 \times 2.0-5.0 \mu \mathrm{m})$ with peritrichous flagella. Catalase- and oxidase-positive. Produces ellipsoidal endospores that lie in a subterminal position in cells and usually cause the sporangia to swell. Colonies on TSA are circular, opaque, cream-coloured and convex with entire margins and are usually $2 \mathrm{~mm}$ in diameter within $48 \mathrm{~h}$ of growth at $30{ }^{\circ} \mathrm{C}$. Growth occurs in the presence of $0-2 \% \mathrm{NaCl}$, at $\mathrm{pH}$ 5-9 (optimum $\mathrm{pH} 6-8$ ) and at $10-37{ }^{\circ} \mathrm{C}$ (optimum $\left.30-35{ }^{\circ} \mathrm{C}\right)$. Hydrogen sulfide is not produced. DNA, casein and Tween 20 are hydrolysed but CM-cellulose, egg yolk, gelatin, Tween 80 , L-tyrosine and xylan are not. In the API 20 NE system, positive for aesculin hydrolysis $(\beta$ glucosidase), $\beta$-galactosidase and assimilation of $\mathrm{D}$-glucose and maltose but negative for nitrate reduction, fermentation of D-glucose, indole production, production of arginine dihydrolase and urease and assimilation of $\mathrm{N}$ acetylglucosamine, adipic acid, L-arabinose, capric acid, Dmannitol, D-mannose, malate, phenylacetic acid and trisodium citrate. In the API $50 \mathrm{CHB}$ system, acids are produced from amygdalin, cellobiose, dulcitol (weakly), aesculin, D-fructose, D-galactose, gentiobiose, D-glucose, lactose, maltose, D-mannose, melezitose, melibiose, methyl- $\alpha$-D-glucopyranoside (weakly), methyl- $\alpha$-D-mannopyranoside, raffinose, L-rhamnose, sucrose, trehalose, turanose and D-xylose; acids are not produced from other substrates. In the API ZYM gallery, acid phosphatase, leucine arylamidase (weakly), esterase (C4), esterase lipase (C8), $\alpha$ - and $\beta$-galactosidase and $\beta$-glucosidase activities are present; but alkaline phosphatase, $N$-acetyl- $\beta$-glucosaminidase, $\alpha$-chymotrypsin, cystine arylamidase, $\alpha$-fucosidase, $\alpha$-glucosidase, $\beta$-glucuronidase, lipase (C14), $\alpha$ mannosidase, naphthol-AS-BI-phosphohydrolase, trypsin and valine arylamidase activities are absent. In the Biolog GP2 Microplate system the following substrates are assimilated: amygdalin, cellobiose, dextrin, D-galactose, gentiobiose, D-gluconic acid, $\alpha$-D-glucose, maltose, maltotriose, melibiose, melezitose, methyl- $\beta$-D-galactoside, raffinose, palatinose, trehalose, stachyose, sucrose and turanose; other substrates are not assimilated. Cells are sensitive to ( $\mu \mathrm{g}$ per disc, unless otherwise indicated): amikacin (30), ampicillin (10), chloramphenicol (30), erythromycin (15), gentamicin (10), kanamycin (30), nalidixic acid (30), penicillin (10 IU), polymyxin B (300 IU), streptomycin (10) tetracycline (30) and vancomycin (30). The major fatty acids are anteiso- $\mathrm{C}_{15: 0}$ $(32.2 \%), \mathrm{C}_{16: 0}(20.1 \%)$ and $\mathrm{C}_{18: 0}(18.1 \%)$. The major polar lipids are diphosphatidylglycerol, phosphatidylethanolamine and unknown aminophospholipids. The diamino acid in the cell-wall peptidoglycan is meso-diaminopimelic acid. The predominant isoprenoid quinone is MK-7.
The type strain, WPCB018 ${ }^{\mathrm{T}}\left(=\mathrm{KCTC} 13280^{\mathrm{T}}=\mathrm{JCM} 16350^{\mathrm{T}}\right)$, was isolated from freshwater collected from Woopo wetland. The DNA G +C content of the type strain is $56.0 \mathrm{~mol} \%$.

\section{Acknowledgements}

This research was supported by the Basic Science Research Program through the National Research Foundation of Korea (NRF) funded by the Ministry of Education, Science and Technology (2010-0006861).

\section{References}

Alexander, B. \& Priest, F. G. (1989). Bacillus glucanolyticus, a new species that degrades a variety of $\beta$-glucans. Int J Syst Bacteriol 39, 112-115.

Ash, C., Priest, F. G. \& Collins, M. D. (1993). Molecular identification of rRNA group 3 bacilli (Ash, Farrow, Wallbanks and Collins) using a PCR probe test. Proposal for the creation of a new genus Paenibacillus. Antonie van Leeuwenhoek 64, 253-260.

Baik, K. S., Park, S. C., Kim, E. M., Bae, K. S., Ahn, J. H., Ka, J. O., Chun, J. \& Seong, C. N. (2008). Diversity of bacterial community in freshwater of Woopo wetland. J Microbiol 46, 647-655.

Breznak, J. \& Costilow, R. N. (2007). Physicochemical factors in growth. In Methods for General and Molecular Microbiology, pp. 309329. Edited by C. A. Reddy, T. J. Beveridge, J. A. Breznak, G. Marzluf, T. M. Schmidt \& L. R. Snyder. Washington, DC: American Society for Microbiology.

Chun, J. (1995). Computer-assisted classification and identification of actinomycetes. $\mathrm{PhD}$ thesis, University of Newcastle.

Chun, J. \& Goodfellow, M. (1995). A phylogenetic analysis of the genus Nocardia with 16S rRNA gene sequences. Int J Syst Bacteriol 45, 240-245.

Chun, J., Lee, J.-H., Jung, Y., Kim, M., Kim, S., Kim, B. K. \& Lim, Y. W. (2007). EzTaxon: a web-based tool for the identification of prokaryotes based on $16 \mathrm{~S}$ ribosomal RNA gene sequences. Int J Syst Evol Microbiol 57, 2259-2261.

Chung, Y. R., Kim, C. H., Hwang, I. \& Chun, J. (2000). Paenibacillus koreensis sp. nov., a new species that produces an iturin-like antifungal compound. Int J Syst Evol Microbiol 50, 1495-1500.

CLSI (2009). Performance standards for antimicrobial susceptibility testing, Nineteenth Informational Supplement. CLSI document M100-S19 (ISBN 1-56238-690-5). Wayne, PA: Clinical and Laboratory Standards Institute.

Dahllöf, I., Baillie, H. \& Kjelleberg, S. (2000). rpoB-based microbial community analysis avoids limitations inherent in 16S rRNA gene intraspecies heterogeneity. Appl Environ Microbiol 66, 3376-3380.

Felsenstein, J. (1985). Confidence limits on phylogenies: an approach using the bootstrap. Evolution 39, 783-791.

Felsenstein, J. (1993). PHYLIP (phylogeny inference package), version 3.5c. Distributed by the author. Department of Genome Sciences, University of Washington, Seattle, USA.

Fitch, W. M. (1971). Toward defining the course of evolution: minimum change for a specific tree topology. Syst Zool 20, 406416.

Fitch, W. M. \& Margoliash, E. (1967). Construction of phylogenetic trees. Science 155, 279-284.

Jukes, T. H. \& Cantor, C. R. (1969). Evolution of protein molecules. In Mammalian Protein Metabolism, vol. 3, pp. 21-132. Edited by H. N. Munro. New York: Academic Press. 
Kanzawa, Y., Harada, A., Takeuchi, M., Yokota, A. \& Harada, T. (1995). Bacillus curdlanolyticus sp. nov. and Bacillus kobensis sp. nov., which hydrolyze resistant curdlan. Int J Syst Bacteriol 45, 515-521.

Kim, B.-C., Lee, K. H., Kim, M. N., Kim, E.-M., Rhee, M.-S., Kwon, O.-Y. \& Shin, K.-S. (2009). Paenibacillus pinihumi sp. nov., a cellulolytic bacterium isolated from the rhizosphere of Pinus densiflora. J Microbiol 47, 530-535.

Komagata, K. \& Suzuki, K. (1987). Lipids and cell-wall analysis in bacterial systematics. Methods Microbiol 19, 161-207.

Kroppenstedt, R. M. (1985). Fatty acid and menaquinone analysis of actinomycetes and related organisms. In Chemical Methods in Bacterial Systematics (Society for Applied Bacteriology Technical Series vol. 20), pp. 173-199. Edited by M. Goodfellow \& D. E. Minnikin. New York: Academic Press.

Lee, J.-S., Lee, K. C., Pyun, Y.-R. \& Bae, K. S. (2003). Arthrobacter koreensis sp. nov., a novel alkalitolerant bacterium from soil. Int J Syst Evol Microbiol 53, 1277-1280.

Mandel, M., Igambi, L., Bergendahl, J., Dodson, M. L., Jr \& Scheltgen, E. (1970). Correlation of melting temperature and cesium chloride buoyant density of bacterial deoxyribonucleic acid. J Bacteriol 101, 333-338.

Marmur, J. \& Doty, P. (1962). Determination of the base composition of deoxyribonucleic acid from its thermal denaturation temperature. J Mol Biol 5, 109-118.

Minnikin, D. E., O'Donnell, A. G., Goodfellow, M., Alderson, G., Athayle, M., Schaal, A. \& Parlett, J. H. (1984). An integrated procedure for the extraction of bacterial isoprenoid quinones and polar lipids. J Microbiol Methods 2, 233-241.

Montefusco, A., Nakamura, L. K. \& Labeda, D. P. (1993). Bacillus peoriae sp. nov. Int J Syst Bacteriol 43, 388-390.

Nakamura, L. K. (1984). Bacillus amylolyticus sp. nov., nom. rev., Bacillus lautus sp. nov., nom. rev., Bacillus pabuli sp. nov., nom. rev., and Bacillus validus sp. nov., nom. rev. Int J Syst Bacteriol 34, 224-226.

Powers, E. M. (1995). Efficacy of the Ryu nonstaining $\mathrm{KOH}$ technique for rapidly determining Gram reactions of food-borne and waterborne bacteria and yeasts. Appl Environ Microbiol 61, 3756-3758.

Saitou, N. \& Nei, M. (1987). The neighbor-joining method: a new method for reconstructing phylogenetic trees. Mol Biol Evol 4, 406-425.

Seldin, L., van Elsas, J. D. \& Penido, E. G. C. (1984). Bacillus azotofixans sp. nov., a nitrogen-fixing species from Brazilian soils and grass roots. Int J Syst Bacteriol 34, 451-456.

Seo, W.-T., Kahng, G.-G., Nam, S.-H., Choi, S.-D., Suh, H.-H., Kim, S.-W. \& Park, Y.-H. (1999). Isolation and characterization of a novel exopolysaccharide-producing Paenibacillus sp. WN9 KCTC 8951P. J Microbiol Biotechnol 9, 820-825.

Shida, O., Takagi, H., Kadowaki, K., Nakamura, L. K. \& Komagata, K. (1997). Emended description of Paenibacillus amylolyticus and description of Paenibacillus illinoisensis sp. nov. and Paenibacillus chibensis sp. nov. Int J Syst Bacteriol 47, 299-306.

Skerman, V. B. D. (1967). A Guide to the Identification of the Genera of Bacteria, 2nd edn. Baltimore: Williams \& Wilkins.

Smibert, R. M. \& Krieg, N. R. (1994). Phenotypic characterization. In Methods for General and Molecular Bacteriology, pp. 607-654. Edited by P. Gerhardt, R. G. E. Murray, W. A. Wood \& N. R. Krieg. Washington, DC: American Society for Microbiology.

Staley, J. T. (1968). Prosthecomicrobium and Ancalomicrobium: new prosthecate freshwater bacteria. J Bacteriol 95, 1921-1942.

Swofford, D. L. (1998). Phylogenetic analysis using parsimony (PAUP), version 4. Sunderland, MA: Sinauer Associates.

Thompson, J. D., Gibson, T. J., Plewniak, F., Jeanmougin, F. \& Higgins, D. G. (1997). The CLUSTAL_X windows interface: flexible strategies for multiple sequence alignment aided by quality analysis tools. Nucleic Acids Res 25, 4876-4882.

Vaz-Moreira, I., Faria, C., Nobre, M. F., Schumann, P., Nunes, O. C. \& Manaia, C. M. (2007). Paenibacillus humicus sp. nov., isolated from poultry litter compost. Int J Syst Evol Microbiol 57, 2267-2271.

Wang, M., Yang, M., Zhou, G., Luo, X., Zhang, L., Tang, Y. \& Fang, C. (2008). Paenibacillus tarimensis sp. nov., isolated from sand in Xinjiang, China. Int J Syst Evol Microbiol 58, 2081-2085.

Wayne, L. G., Brenner, D. J., Colwell, R. R., Grimont, P. A. D., Kandler, O., Krichevsky, M. I., Moore, L. H., Moore, W. E. C., Murray, R. G. E. \& other authors (1987). International Committee on Systematic Bacteriology. Report of the ad hoc committee on reconciliation of approaches to bacterial systematics. Int J Syst Bacteriol 37, 463-464.

Yamaguchi, S. \& Yokoe, M. (2000). A novel protein-deamidating enzyme from Chryseobacterium proteolyticum sp. nov., a newly isolated bacterium from soil. Appl Environ Microbiol 66, 3337-3343.

Yoon, J.-H., Yim, D. K., Lee, J.-S., Shin, K.-S., Sato, H. H., Lee, S. T., Park, Y. K. \& Park, Y.-H. (1998). Paenibacillus campinasensis sp. nov., a cyclodextrin-producing bacterium isolated in Brazil. Int $J$ Syst Bacteriol 48, 833-837.

Yumoto, I., Hirota, K., Yamaga, S., Nodasaka, Y., Kawasaki, T., Matsuyama, H. \& Nakajima, K. (2004). Bacillus asahii sp. nov., a novel bacterium isolated from soil with the ability to deodorize the bad smell generated from short-chain fatty acids. Int J Syst Evol Microbiol 54, 1997-2001. 